Original research article

\title{
PREDICTING PHARMACOKINETIC PROFILES OF SUNFLOWER'S (Helianthus annuus L.) ACTIVE COMPOUNDS USING IN SILICO APPROACH
}

\author{
Alif Firman Firdausy ${ }^{1}$, Roihatul Muti'ah ${ }^{1}$ and Eka Kartini Rahmawati ${ }^{1}$ \\ ${ }^{1}$ Department of Pharmacy, Faculty of Medicine and Health Sciences UIN Maulana Malik Ibrahim, \\ Malang, Indonesia \\ *Corresponding author \\ Email: aliffirman.firdausy@gmail.com
}

Keywords:

Hellianuol

Sunflower

Pharmacokinetic profie pkCSM online tool

\begin{abstract}
Introduction: Sunflower (Heliantus annuus L.) widely known as medicinal plant for treating several diseases, such as hypertension, allergy, pain, inflammation, and cancer. It contains various bioactive compounds which some of them were hellianuols. Hellianuols are a sesquiterpene lactones which marked by benzene fused 6- to 8-membered cyclic ether ring structure. To make sure that hellianuols were adequate for development as a new chemical entities, we predicted some pharmacokinetic parameters of several hellianuols compounds (A to L) through in silico approach. Methods: We constructed 3 dimensional structures of hellianuol $A, B, C, D, E, F, G, H, I, J, K$ and $L$ then generated the SMILE codes of each compound. These codes then used as main material for running pkCSM online tool to predict absorption, distribution, metabolism, and excretion profile of each compounds. Results: Helianuols predicted to be well absorbed in intestine (90.793\% to $95.384 \%$ permeability), skin (Log Kp: -2.662 to -3.570), and high permeability against monolayer Caco-2 cell lines ( $\log P_{\text {app: }}: 1.186$ to $\left.1.341 \times 10^{-6} \mathrm{~cm} / \mathrm{s}\right)$. Unfortunately, it had been predicted that hellianuols poorly distributed in the body based on volume of distribution at steady state (VDSs: 0.094 to 0.317) value. But its also predicted that most of hellianuols had a capability to pass through blood-brain barriers (LogBBB: up to 0.389) and penetrated into central nervous system as well. Only hellianuol $G, H$ and $K$ predicted to be metabolized by CYP1A2 inhibitor and only hellianuol A, B, D, $E$ and K metabolized by CYP2C19. Also predicted that hellianuols were excreted in around 0.719 to $1.082 \mathrm{mg} / \mathrm{kg} / \mathrm{day}$. Conclusion: Hellianuols contained in leaf aqueous extract of sunflower predicted to be a good new pharmaceutical entities candidate based on its pharmacokinetic profiles.
\end{abstract}




\section{INTRODUCTION}

The discovery of new chemical entities originated from plants has attracted much attention in the last two decades. It is becoming more important to implement modern methodologies and innovative strategy for designing an effective, safe, and acceptable new drug (1). Qualified drug must meet some standards of pharmacokinetics aspects, abbreviated with ADME (Absorption, Distribution, Metabolism, Excretion). It takes more time and also costs for conducting in vivo and in vitro data to assure that drug candidates are good in absorption, distribution, metabolism, and excretion. Predicting pharmacokinetic aspects through in silico and computational modelling is important nowadays, especially to cut off time and cost requirement of a new drug discovery (2).

Macias et al. were succesfully isolated and elucidated 12 kinds of sesquiterpene compounds from aqueous extract of Helianthus annuus L. cv. SH222 leaves, namely: Hellianuol A, B, C, D, E, F, G, H, I, J, K, and L $(3,4)$. Hellianuols structure marked with the presence of benzenefused 6- to 8membered cyclic ether ring so they are included in sesquiterpene compounds (5).

Some hellianuol $(\mathrm{B}, \mathrm{G}, \mathrm{H})$ have a benzoxepine ring inside their structure. The structure of hellianuols A-L represented in Figure 1. According to Kuntala et al., derivatives of benzoxepine showed various pharmacological effects such as: antibacterial and anticancer activity, anti-hypertension agent, estrogen receptor modulator and anti-HIV agent (6-10). Hellianuols itself widely observed as natural herbicide agents due to its herbicidal activities against wide range of monocotyledons and dicotyledons (11).

\section{MATERIALS AND METHODS}

The structure of twelve hellianuols were designed using ChemBio2D Draw Ultra v12.0 (CambridgeSoft) and obtained the SMILE string of each compound.
Using the SMILE string, we predicted absorption, distribution, metabolism and excretion (ADME) profiles of hellianuol A-L. The prediction of twelve compounds was conducted using pkCSM online tool (http://biosig.unimelb.edu.au/pkcsm/predi ction).

\section{RESULTS AND DISCUSSION}

The pharmacokinetic properties of hellianuol A-L according to pkCSM online tool are presented in Table 1 .

\section{Absorption}

Hellianuol A-L exhibited high value (90.763\% to $95.384 \%)$ of predicted \% human intestinal absorption as their values are above $80 \%$ (12). Hellianuol A$\mathrm{L}$ predicted to be skin permeable as their skin permeability constant values $(-2.662$ to $-3.570 \operatorname{logKp}$ ) are below -2.5 (13). The ability of hellianuols to transport through intestinal mucosa membrane were predicted by apparent permeabilites of Caco-2 cell line parameter $\left(P_{\text {app }}\right)(14)$.

According to US FDA, $P_{\text {app }}$ values $<1 \times 10^{-6} \mathrm{~cm} / \mathrm{s}$ indicate poor permeability and $P_{\text {app }}>10 \times 10^{-6} \mathrm{~cm} / \mathrm{s}$ indicate high permeability, then hellianuol A-L exhibited 1.186 to $1.341 \times 10^{-6} \mathrm{~cm} / \mathrm{s}$ $\log P_{\text {app }}(15)$, it could be predicted that hellianuol A-L were poorly permeable through Caco-2 cell line. Another aspect of absorption were predicted through heliannuols interactions to P-glycoprotein (P-gp), a transporter protein that play several important roles during drug absorption, especially for expelling molecules out of cells (16). Based on their structures, there are eight hellianuols (A, $\mathrm{B}, \mathrm{C}, \mathrm{D}, \mathrm{E}, \mathrm{G}, \mathrm{H}, \mathrm{L}$ ) predicted to be the substrate of P-gp, thus only hellianuol F, I, $\mathrm{J}$ and $\mathrm{K}$ could be absorbed without extracted out of cells.

\section{Distribution}

Steady state volume of distribution $\left(\mathrm{Vd}_{\mathrm{ss}}\right)$ is a pharmacokinetic parameter to estimate drug distribution within tissues. The higher the $\mathrm{Vd}_{\mathrm{ss}}$ value, the more drug concentration is distributed into the tissue 


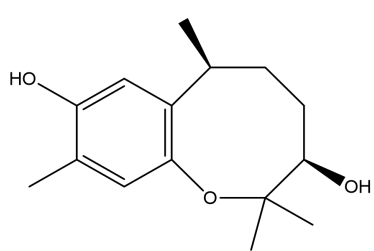

Hellianuol A

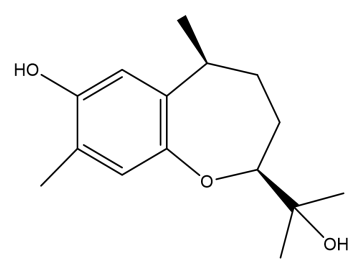

Hellianuol D<smiles>Cc1cc2c(cc1O)[C@@H](C)[C@H](O)C=CC(C)(C)O2</smiles>

Hellianuol G<smiles>Cc1cc2c(cc1O)[C@@]1(C)O[C@@H]1C[C@@H](C(C)(C)O)O2</smiles>

Hellianuol J

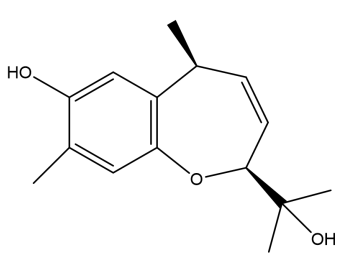

Hellianuol B<smiles>C=C[C@H]1C[C@H](C(C)(C)O)Oc2cc(C)c(O)cc21</smiles>

Hellianuol E<smiles>Cc1cc2c(cc1O)[C@@H](C)[C@H](O)C=CC(C)(C)O2</smiles>

Hellianuol $\mathrm{H}$<smiles>Cc1cc2c(cc1O)[C@@H](C)CCC(=O)C2(C)C</smiles>

Hellianuol K<smiles>C=C[C@H]1C[C@H](O)C(C)(C)Oc2cc(C)c(O)cc21</smiles>

Hellianuol C<smiles>Cc1cc2c(cc1O)[C@@H](C)C(=O)C[C@@H](C(C)(C)O)O2</smiles>

Hellianuol F<smiles>Cc1cc2c(cc1O)[C@@]1(C)O[C@H]1C[C@@H](C(C)(C)O)O2</smiles>

Hellianuol<smiles>Cc1cc2c(cc1O)[C@@H](C)[C@H](O)C[C@@H](O)C2(C)C</smiles>

Hellianuol L

Figure 1. Chemical structures and common names of the 12 hellianuol compounds investigated in this study.

than plasma (17). $\mathrm{Vd}_{\mathrm{ss}}$ considered low if its logarithmic form under $-0.15\left(\log \mathrm{Vd}_{\mathrm{ss}}\right.$ $<-0.15)$ and high if above $0.45\left(\log \mathrm{Vd}_{\mathrm{ss}}>\right.$ 0.45) (18). Hellianuols showed moderately distributed with $\log \mathrm{Vd}_{\mathrm{ss}}$ values range between $0.094-0.317$.

Based on pkCSM result, $\operatorname{LogBB}$ values of hellianuols vary between -0.616 and 0.389. Hellianuol A, B, D, G, H, and $\mathrm{K}$ have such chemical structures that allows them to readily cross the bloodbrain barrier $(\operatorname{LogBB}>0.3)$, while hellianuol C, E, F, I, J, and $\mathrm{K}$ predicted as moderately distributed to the brain ( $\operatorname{LogBB}<0.3)(18)$. It is also predicted that hellianuol A, B, C, and D would shows such good in situ brain perfusions result $(\log \mathrm{PS}>-2)$, while only hellianuol L showed low prediction value (LogPS= 3.189).

PkCSM could predict how molecules are distributed within the body based on their structure. From the data supplemented in Table 1, we predicted 
that helainnuols could be well distributed in the body. It could be assumed as well that some hellianuols would be distributed to the brain. Especially hellianuol A, B, and $\mathrm{D}$ which have high values of $\operatorname{LogBB}$ and LogPS, so they are predicted to readily cross the blood-brain barrier and penetrated directly into the central nervous system $(19,20)$.

\section{Metabolism}

Cytochrome $\mathrm{P} 450 \mathrm{~s}$ is an important enzyme for xenobiotics metabolism in liver. Two main subtype of cytochrome P450 are CYP2D6 and CYP3A4. Metabolism of hellianuols are predicted based on models for different CYP isoforms (CYP2D6, CYP3A4, CYP1A2, CYP2C19, CYP2C9, CYP2D6, and CYP3A4) $(18,21)$. The results showed that hellianuol $\mathrm{G}$ and $\mathrm{H}$ were predicted to be CYP1A2 inhibitor, and hellianuol A, $\mathrm{B}, \mathrm{D}$, and $\mathrm{E}$ were predicted to be CYP2C19 inhibitor. This suggested that hellianuols may not metabolised directly in liver as they were not being the substrate of Cytochrome P450 enzymes family, but hellianuol A, B, D, E, G, H, K may affect another drug metabolisms, as they were predicted could be the Cytochrome P450 inhibitor.

\section{Excretion}

Excretion profile of hellianuols were predicted using drug total clearance parameter $\left(\mathrm{CL}_{\mathrm{tot}}\right)$. Total clearance is a combination of hepatic and renal clearance, measured in $\log \mathrm{ml} / \mathrm{min} / \mathrm{kg}$ (22). The prediction results show that the total clearance of hellianuol $\mathrm{C}$ is the highest followed by hellianuol E, B, D, K, A, G, $\mathrm{H}, \mathrm{F}, \mathrm{L}, \mathrm{I}$ and $\mathrm{J}$. Indicating that bioavailability of hellianuol $\mathrm{J}$ is the highest. The results also suggested that hellianuols may not be the substrates of Organic Cation transporter 2 (OCT2), a renal uptake transporter that plays an important role in drug elimination through kidney. From the result above, we can considerate that hellianuols excreted through kidney in another mechanism besides OCT2.

\section{CONCLUSION}

Based on in silico pharmacokinetic profiles study of hellianuol A-L contained in aqueous extract of Helianthus annuus $\mathrm{L}$. cv. SH-222 leaves using pkCSM online tool, it can be concluded that overall could be well absorbed through oral administration. Hellianuols were quite promising to be developed as a an anticancer drug especially for brain cancer, as they were predicted to be able to penetrated blood-brain barrier into central nervous system. Their properties exhibited such a good pharmacokinetics as well.

This study widely opens opportunities for further research on hellianuols, especially to produce more accurate result prospectively in in vitro and in vivo studies.

\section{ACKNOWLEDGEMENTS}

We thank the Department of Pharmacy, Faculty of Medicine and Health Sciences UIN Maulana Malik Ibrahim Malang for providing us a good internet access to do our research.

\section{REFERENCES}

1. Chiaradia LD, Martins PGA, Cordeiro MNS, Guido RVC, Ecco G, Andricopulo $\mathrm{AD}$, et al. Synthesis, biological evaluation, and molecular modeling of chalcone derivatives as potent inhibitors of Mycobacterium tuberculosis protein tyrosine phosphatases (PtpA and PtpB). J Med Chem. 2012;55(1):390-402.

2. Hosea NA, Jones HM. Predicting pharmacokinetic profiles using in silico derived parameters. Mol Pharm. 2013;10(4):1207-15.

3. Macías FA, Varela RM, Torres A, Molinillo JMG. Hellianuol E. A novel bioactive sesquiterpene of the heliannane family. Tetrahedron Lett. 1999;40(25):4725-8.

4. Macías FA, Varela RM, Torres A, Molinillo JMG. New bioactive plant hellianuols from cultivar sunflower leaves. J Nat Prod. 1999;62(12):1636-9.

5. Chen K, Li Y, Du Z, Tao Z. Total Syntheses of Hellianuols: An Overview. Synth Commun. 2015;45(6):673-701.

6. Kuntala N, Telu JR, Banothu V, Babu NS, Anireddy JS, Pal S. Novel 
benzoxepine-1,2,3-triazole hybrids: Synthesis and pharmacological evaluation as potential antibacterial and anticancer agents. Med Chem Commun. 2015;6(9):1612-9.

7. Tandon VK, Chandra A. 3,4-Dihydro1(2H)-Benzoxepine. 1993;6:221-5.

8. Heffron TP, Wei B, Olivero A, Staben ST, Tsui V, Do S, et al. Rational design of phosphoinositide 3-kinase inhibitors that exhibit selectivity over the phosphoinositide 3-kinase isoform. J Med Chem. 2011;54(22):7815-33.

9. Lloyd DG, Hughes RB, Zisterer DM, Williams DC, Fattorusso C, Catalanotti B, et al. Benzoxepin-Derived Estrogen Receptor Modulators: A Novel Molecular Scaffold for the Estrogen Receptor. 2004;(Scheme 1):5612-5.

10. Eto MS, Ramaki YA, Moto HI, Ikawa KA, Da TO. Orally Active CCR5 Antagonists as Anti-HIV-1 Agents 2: Synthesis and Biological Activities of Anilide Derivatives Containing a Pyridine N -Oxide. 2004;52(7):818-29.

11. Doi F, Ohara T, Ogamino T, Sugai T, Higashinakasu $\mathrm{K}$, Yamada $\mathrm{K}$, et al. Plant-growth inhibitory activity of hellianuol derivatives. Phytochemistry. 2004;65(10):1405-11.

12. Chander S, Tang CR, Al-Maqtari HM, Jamalis J, Penta A, Hadda T Ben, et al. Synthesis and study of anti-HIV-1 RT activity of 5-benzoyl-4-methyl-1,3,4,5tetrahydro-2H-1,5-benzodiazepin-2-one derivatives. Bioorg Chem [Internet]. 2017;72:74-9. Available from: http://dx.doi.org/10.1016/j.bioorg.2017.0 3.013

13. Hassan M, Shahzadi S, Seo SY, Alashwal H, Zaki N, Moustafa AA. Molecular docking and dynamic simulation of AZD3293 and solanezumab effects against BACE1 to treat alzheimer's disease. Front Comput Neurosci. 2018;12(June):1-11.

14. O'Hagan S, Kell DB. The apparent permeabilities of Caco-2 cells to marketed drugs: Magnitude, and independence fromboth biophysical properties and endogenite similarities. PeerJ. 2015;2015(11).

15. FDA. Waiver of In Vivo Bioavailability and Bioequivalence Studies for Immediate-Release Solid Oral Dosage Forms Based on a Biopharmaceutics Classification System: Guidance for Industry [Internet]. 1005598 FNL 2017. Available from: https://www.fda.gov/media/70963/downl oad

16. Lagorce D, Douguet D, Miteva MA, Villoutreix BO. Computational analysis of calculated physicochemical and ADMET properties of protein-protein interaction inhibitors. Sci Rep. 2017;7(April):1-15.

17. Yates JWT, Arundel PA. On the Volume of Distribution at Steady State and Its Relationship With Two-Compartmental Models. J Pharm Sci [Internet]. 2008 Jan;97(1):111-22. Available from: https://linkinghub.elsevier.com/retrieve/p ii/S0022354916324479

18. pkCSM. Theory - How to interpret pkCSM results [Internet]. 2020 [cited 2020 Feb 17]. Available from: http://biosig.unimelb.edu.au/pkcsm/theor $\mathrm{y}$

19. Pires DEV, Blundell TL, Ascher DB. pkCSM: Predicting small-molecule pharmacokinetic and toxicity properties using graph-based signatures. J Med Chem. 2015;58(9):4066-72.

20. Norinder U, Haeberlein M. Computational approaches to the prediction of the blood-brain distribution. Adv Drug Deliv Rev. 2002;54(3):291313.

21. Han Y, Zhang J, Hu CQ, Zhang X, Ma B, Zhang P. In silico ADME and toxicity prediction of ceftazidime and its impurities. Front Pharmacol. 2019;10(APR):1-12.

22. Hardjono S. Prediksi Sifat Farmakokinetik , Toksisitas dan Aktivitas sebagai Calon Obat Antikanker melalui Pemodelan Molekul ( Prediction of Pharmacokinetic Properties, Toxicit and Derivatives as Anticancer Drugs Candidate through Molecular Modeling ). 2017;14(2):246-55. 
Table 1. Predicted ADME properties of hellianuols

\begin{tabular}{|c|c|c|c|c|c|c|c|c|c|c|c|c|}
\hline \multirow{2}{*}{ Properties } & \multicolumn{12}{|c|}{ Hellianuol } \\
\hline & $\mathbf{A}$ & B & $\mathrm{C}$ & D & $\mathbf{E}$ & $\mathbf{F}$ & G & $\mathbf{H}$ & I & $\mathbf{J}$ & $\mathbf{K}$ & $\mathbf{L}$ \\
\hline $\begin{array}{l}\text { Empirical } \\
\text { formula }\end{array}$ & $\mathrm{C}_{14} \mathrm{H}_{20} \mathrm{O}_{3}$ & $\mathrm{C}_{15} \mathrm{H}_{20} \mathrm{O}_{3}$ & $\mathrm{C}_{16} \mathrm{H}_{22} \mathrm{O}_{3}$ & $\mathrm{C}_{15} \mathrm{H}_{22} \mathrm{O}_{3}$ & $\mathrm{C}_{16} \mathrm{H}_{22} \mathrm{O}_{3}$ & $\mathrm{C}_{15} \mathrm{H}_{20} \mathrm{O}_{4}$ & $\mathrm{C}_{15} \mathrm{H}_{20} \mathrm{O}_{3}$ & $\mathrm{C}_{15} \mathrm{H}_{20} \mathrm{O}_{3}$ & $\mathrm{C}_{15} \mathrm{H}_{20} \mathrm{O}_{4}$ & $\mathrm{C}_{15} \mathrm{H}_{20} \mathrm{O}_{4}$ & $\mathrm{C}_{15} \mathrm{H}_{20} \mathrm{O}_{3}$ & $\mathrm{C}_{15} \mathrm{H}_{22} \mathrm{O}_{4}$ \\
\hline $\begin{array}{l}\text { Molecular } \\
\text { weight }(\mathrm{g} / \mathrm{mol})\end{array}$ & 236.31 & 248.32 & 262.34 & 250.33 & 262.34 & 264.32 & 248.32 & 248.32 & 264.32 & 264.32 & 248.32 & 266.33 \\
\hline \multicolumn{13}{|c|}{ Absorption } \\
\hline $\begin{array}{l}\text { Intestinal } \\
\text { absorption (\% } \\
\text { absorbed) }\end{array}$ & 90,793 & 91,239 & 91,473 & 90,763 & 91,369 & 94,255 & 93,800 & 93,800 & 92,542 & 92,542 & 93,593 & 95,384 \\
\hline $\begin{array}{l}\text { Skin } \\
\text { permeability } \\
(\log \mathrm{Kp})\end{array}$ & -3.21 & $-3,218$ & $-3,241$ & $-3,186$ & $-3,215$ & $-3,570$ & $-2,942$ & $-2,942$ & $-3,314$ & $-3,314$ & $-2,662$ & $-3,109$ \\
\hline $\begin{array}{l}\text { Caco-2 } \\
\text { permeability } \\
\left(\log P_{\text {app }} \text { in } 10^{-6}\right. \\
\mathrm{cm} / \mathrm{s})\end{array}$ & 1.297 & 1,283 & 1,252 & 1,295 & 1,295 & 1,248 & 1,287 & 1,287 & 1,186 & 1,186 & 1,341 & 1,206 \\
\hline $\begin{array}{l}\text { P-glycoprotein } \\
\text { substrate }\end{array}$ & Yes & Yes & Yes & Yes & Yes & No & Yes & Yes & No & No & No & Yes \\
\hline $\begin{array}{l}\text { P-glycoprotein } \\
\text { I inhibitor }\end{array}$ & No & No & No & No & No & No & No & No & No & No & No & No \\
\hline $\begin{array}{l}\text { P-glycoprotein } \\
\text { II inhibitor }\end{array}$ & No & No & No & No & No & No & No & No & No & No & No & No \\
\hline \multicolumn{13}{|c|}{ Distribution } \\
\hline $\mathrm{Vd}_{\mathrm{ss}}(\log \mathrm{L} / \mathrm{kg})$ & 0.094 & 0,150 & 0,076 & 0,159 & 0,172 & 0,096 & 0,317 & 0,317 & 0,270 & 0,270 & 0,193 & 0,115 \\
\hline $\begin{array}{l}\text { BBB } \\
\text { permeability } \\
(\operatorname{logBB})\end{array}$ & 0.341 & 0,311 & 0,296 & 0,313 & 0,021 & 0,092 & 0,389 & 0,389 & 0,112 & 0,112 & 0,378 & $-0,616$ \\
\hline \multicolumn{13}{|c|}{ Metabolism } \\
\hline $\begin{array}{l}\text { CYP2D6 } \\
\text { substrate }\end{array}$ & No & No & No & No & No & No & No & No & No & No & No & No \\
\hline $\begin{array}{l}\text { CYP3A4 } \\
\text { substrate }\end{array}$ & No & No & No & No & No & No & No & No & No & No & No & No \\
\hline $\begin{array}{l}\text { CYP1A2 } \\
\text { inhibitor }\end{array}$ & No & No & No & No & No & No & Yes & Yes & No & No & Yes & No \\
\hline
\end{tabular}


Predicting Pharmacokinetic Profiles Of Sunflower's (Helianthus annuus L.) Active Compounds Using In Silico Approach

\begin{tabular}{|c|c|c|c|c|c|c|c|c|c|c|c|c|}
\hline $\begin{array}{l}\text { CYP2C19 } \\
\text { inhibitor }\end{array}$ & Yes & Yes & No & Yes & Yes & No & No & No & No & No & Yes & No \\
\hline Properties & \multicolumn{12}{|c|}{ Hellianuol } \\
\hline & $\mathbf{A}$ & B & $\mathbf{C}$ & D & $\mathbf{E}$ & $\mathbf{F}$ & $\mathbf{G}$ & $\mathbf{H}$ & I & $\mathbf{J}$ & $\mathbf{K}$ & $\mathbf{L}$ \\
\hline $\begin{array}{l}\text { CYP2D6 } \\
\text { inhibitor }\end{array}$ & No & No & No & No & No & No & No & No & No & No & No & No \\
\hline $\begin{array}{l}\text { CYP3A4 } \\
\text { inhibitor }\end{array}$ & No & No & No & No & No & No & No & No & No & No & No & No \\
\hline \multicolumn{13}{|c|}{ Excretion } \\
\hline $\begin{array}{l}\text { Total clearance } \\
(\log \mathrm{ml} / \mathrm{min} / \mathrm{kg})\end{array}$ & 0,947 & 1,011 & 1,082 & 0,948 & 1,078 & 0,895 & 0,905 & 0,905 & 0,719 & 0,719 & 0,974 & 0,824 \\
\hline $\begin{array}{l}\text { Renal OCT2 } \\
\text { substrate }\end{array}$ & No & No & No & No & No & No & No & No & No & No & No & No \\
\hline
\end{tabular}

ADME, absorption, distribution, metabolism, excretion; $P_{a p p}$, apparent permeability coefficient; Kp, skin permeability constant; Vd $d_{\text {ss, }}$ volume of distribution at steady state; BBB, blood-brain barrier; BB, blood-brain; CNS, central nervous system; PS, permeability-surface area; OCT2, organic cation transporter-2 